\title{
M-Payment as Financial Inclusion Strategy in Islamic Boarding School Cooperatives
}

\author{
B APramuka, ${ }^{1, *}$ P D I Kusuma ${ }^{1}$, Sugiarto ${ }^{1}$ \\ ${ }^{1}$ School of Accounting Faculty of Economics and Business Universitas Jenderal Soedirman \\ Indonesia
}

*Corresponding author: bpramuka@,gmail.com

\begin{abstract}
Financial inclusion refers to the use of financial services such as electronic money. Digital money receives tremendous attention globally, from buyers to sellers, as an alternative form of payment. The passions on this technology enormous and infectious, therefore attracting more followers from large merchant to smaller one including the cooperative. School cooperative serves as a center of economic with a wide range of activities, such as mini market, canteen, to serve the needs of students, teachers, and people in the surrounding area. One of the programs launched by the Central Bank of Indonesia is a financial inclusion to increase the financial literacy of people living in the remote area. In this case, Islamic conventional boarding school cooperative can become influencers in most of the surrounding community to attract people's interest to adopt the technology. The purpose of this inquiry is to find out factors influencing the adoption of mobile payment and user's intention and decision to adopt m-payment. Authors proposed an innovative research model based on the theory of technology acceptance model with the innovation characteristics of the diffusion of innovations, perceived security and intention to recommend the technology. The research model has empirically tested at 205 employees Islamic boarding schools across four regions. The independent variables under study include perceived ease of use, perceived usefulness, perceived credibility, subjective norms, and trust while the dependent variables are mobile payment adoption and intention to recommend the technology. The study uses structural equation modeling as a tool for analysis. The result indicated that perceived ease of use, perceived usefulness, and subjective norms have a significant influence on the adoption of mobile payment. The study also confirmed the relevance of users' intention to recommend mobile payment technology. Thus, future research needs to include social media campaigns and technology adoption studies. For researchers, the result of this study act as a basis for further refinement of personal technology acceptance model. For practitioners, understanding the key constructs is crucial to design, refine, and implement mobile payment services, applications, and products that achieve high consumer acceptance, value, and high rates of positive recommendations in social networks.
\end{abstract}

\section{Introduction}

The financial inclusion phenomenon is currently the center of attention in some countries. Limited knowledge and experience to use financial services is a barrier for certain parties to get financial services. Financial inclusion hasgained attention from academics and policymakers for several reasons such as it has a positive impact on theeconomic development of a country [11], enhancing world development $[5,41]$ and sustainable development [22]. Financial inclusion affects both the macro and microeconomics of a nation. At the micro level individuals who do not have a bank account shall not receive benefits in the form ofincreased value of 
savings [4,5], By possessing an account a women shall have better economic empowerment $[6,20]$, as well as entrepreneurial productive consumption and investment [4] .

Islamic traditional boarding schools provide educational services to the surrounding people regardless of their social status. Most schools are located in rural areas to provide an opportunity for people in rural areas to participate in the education process. Therefore, the schools have the potential to act as a distribution channel in providing access to the majority of people in rural areas. Previous research shows that "disadvantaged people" come from women, young and the poor [20,41]. One of the factors that drive individuals to use financial services is ease of access. Individuals use financial services to meet several basic needs including education, health, and shelter, starting and operating a business. Financial inclusion increases poverty alleviation and promotes economic growth $[7,8]$.

In the digital era access to financial services should be open to anyone. The digital era stimulates the growth of internet-based business activities. The number of mobile phone users has increased sharply and massively throughout the world. Technology innovation has an indispensable role in expanding access of all parties to financial services, so there is no more financial exclusion. People who do not have a formal bank account can use cellular technology to conduct transactions such as paying a taxi, using go pay. High interest in the use of financial technology has emerged since 2004 [27]. Even among the 20 percent of the poorest households, almost 7 out of 10 have cell phones [17].

This paper uses technology acceptance and innovation by individuals to explain the behavior of the use of information technology in the financial sector. What are the factors that influence the interest of Islamic boarding school cooperative managers to use digital financial services? The results of this study contributed to the development of the literature on digital financial inclusion in Indonesia. The Central Bank of Indonesia initiates to develop an ecosystem of non-cash payments by implementing e-money in Islamic boarding schools. However, data on the potential for digitizing financial services for Islamic boarding schools are not yet available.

\section{Literature Review}

\subsection{Financial Inclusion at Individual Levels}

Although previous research on financial inclusion is enormous, few discussed financial inclusion policies at the individual level. With financial inclusion strategy, the Indonesian government expects to narrow down the exclusion for certain circles such as women, young people and the poor. To date, the literature on financial inclusion across the country rely on the state-level proxy based on the data collected by the policy-making, in this case, the Central Bank [7,19,21, Ponce, \& Mylenko, 2010). Non-asymmetric information narrows the generalization of existing research because data from central and macro banks is difficult to translate at the micro level, for example how the government policies increase the financial accessas individual differences in terms of income level, gender, location of residence, or age [5; Dupas et al., 2012).

Specific interventions can encourage the use of digital-based Instruments due to the perception of the benefits of the device [6]. Financial inclusions provide some benefit to the individual in the form of low-cost accounts, financial security, improve networking, as well as legal rights. Nonetheless, the regular benefits have not yet motivated the disadvantaged group 
(women and the poor) to use financial services. Some of the reported barriers include money shortage, and there are no immediate needs for bank accounts and lack of trust. Therefore, the government policies to promote inclusion can increase the likelihood that people perceive financial services are within their reach (Allen et al., 2016).

\subsection{The Feature of E-Money}

The results of research in the field of financial management related to the digital economy is the emergence of digital finance and financial inclusion in the pieces of literature [28]. Digital banking through financial technology has a positive impact on financial composition for developing countries and developed countries because the digital economy provides individual comfort. The marketing field is carried out by researchers (Lu, Chang, \& Yu, 2013) about online retailer's consumer perception of e-loyalty intentions reported that the higher the online retailer's consumers, the more likely consumers to make purchases online.The phenomenal growth in cellular technology has made it easy for consumers to transact. Consumers do not need to bother carrying cash because transaction payments can be made using a cellular device. Mobile-based payments can be categorized into three perspectives, namely foreign mobile commerce, mobile proximity payments, and peer-to-peer mobile [26].

Payment technology using mobile phones also has several limitations which can disrupt transactions such as ergonomics and usability of devices such as small screen size and small keyboard [25], unstable internet connection [37], complicated and tedious payment [33], confidentiality during authentication [9]. Therefore, mobile payment users require more significant effort and high learning speed to use the m-payment application which sounds discouraging. To increase users' interest in using e-money, the payment must be simple, easy to use, and do not require much energy to execute it [24].

\subsection{The Technology Acceptance Theory}

The potential of mobile payment in the future is enormous. Small firms have started to use digital payments for several reasons such as consumer demands and peer pressure. The euphoria has spread over the Islamic boarding schools, where parents have demanded an easy way of paying their children's' tuition due to geographical constraints. Most of the students who study at the boarding schools come from the distance. Likewise, the community living around the schools have limited access to financial services which requires them to travel to the city for payment of bills. As a consequence, the use of digital payment by Islamic boarding schools does not just prosper the pupil but also the surrounding people.

The limited number of schools have adopted digital payment. Among the factors influencing the adoption, the decision is the perceived usability and perceived ease of use of the technology [10]. This theory explains some of the reasons for individuals take electronic mail systems include lower operational costs and the speed of information spread. Mobile payment is voluntary and is used by individuals for the benefit of transactions that are generally personal. Therefore, all adoption costs of m-payment are borne by individuals and adoption decisions are not solely based on practical reasons. To use an m-payment, a person must have sufficient knowledge and skills about [35]. 


\subsection{The Research Model}

Perception against Compatibility of a technology depends on the extent to whichinnovation canprovide meaningful experience and ability to meet the needs of theuser wholeness, as well as offering better values for living. Almost all banks in Indonesia have proposed a mobile payment to anticipate growing business transactions. With the emergence of virtual business during the disruptive era (such as online transportation and online shopping), consumers in Indonesia regardless of their backgrounds have used $\mathrm{m}$ payment [4]. The financial technology does not only offered by financial institutions. Some of the firms providing financial technology include cellular providers (t-money), Telkom, Gojek, Grab, and Tokopedia. M-payment is ubiquitous because it allows for faster, safer and reliable financial services.

Perception of ease of use means that technology tools are simple to use [38]. The first step to do before start using a tool is understanding the complexity of the technology itself. Therefore, perceived ease of use is an essential determinant of technology adoption. Moreover, users also consider some benefits obtained from adopting technology as an important influencer. The application of a mobile payment provides some gains in the form of minimum fees, convenient to use. When consumers feel that mobile payment is easy to learn and use, they will be more likely to adopt the innovation. Consumers first impression of a technology offered is an essential determinant of adoption decision. When consumers believe that they will succeed in utilizing the technology, then the choice is immediately executed. In other words, the ease of perception has a positive effect on the intention to use a technique which later is followed by adoption [15]. Past studies have also discussed on the antecedents of consumer decision to adopt mobile payments [29,32,33,34,38]

Perceive the benefits of a technology tool refers to the relative advantages of a technology that can improve individual performance [38]. Understanding of benefits can increase an individual's desire to adopt a system [40]. Consumers get greater benefits by using online transactions using mobile devices. If compared with traditional epayment methods, consumers who use m-payments benefit from services that are easy and fast. A study by Tan et al., (2014)at Malaysia concludes that consumer perception of high benefits will result in a higher intention to adopt m-payment. Similarly, Teo et al. [34] show that $\mathrm{m}$-payment adoption is useful regarding time savings and portability.

The use of technology in transactions does not mean without risk. From hard perspectives, a technique should possess multiple levels of a security system to prevent hijacking. The phenomena of increasing cybercrime are discouraging and become a severe challenge to technology adoption. The development of hardware should be accompanied with a soft approach. To improve one's attitude towards technology we need to strengthen the power of the subjective norms. For example by providing education about religious standards and legal rules that are expected to control behavior (Adawiyah, Pramuka, Najmudin, and Jati, $2015 ; 31]$.

Perceptionsofsecurity risks are an essential factor that determines consumers' decisions on whether or not to adopt a technology [18]. The knowledge of protection against the risks of using cellular transactions is crucial. The risk of losing confidential data that causes financial losses needs to be well anticipated to motivate users to adopt mpayment. Perception of security in transactions has a positive effect on the intention to take mpayment. 
Trust starts from a belief that everyone is sincere in his or her words, attitude and behavior. Hence the technology of $\mathrm{m}$-payment offered to the public is carefully prepared to prevent data leakage. The level of trust in adopting m-payment assumes that everyone will not behave opportunistically by expecting the promised service (W. Adawiyah, 2015). It will be more difficult for sellers and buyers to build online trust because there is no interaction between the two parties while performing the transactions. The excellent system offers protection to users' data, assets during the online deals.

\section{Material and Methods}

This research is quantitative in nature. The research model was empirically tested at Islamic traditional boarding schools across four regions. The independent variables under study include perceived ease of use, perceived usefulness, perceived credibility, subjective norms, and trust while the dependent variables are mobile payment adoption and intention to recommend the technology. There were 27 items used in the questionnaire to measure those variables. The study uses structural equation modeling as a tool for analysis. A survey distributed to respondents using purposive sampling. Criteria for respondents are boarding school cooperative managers who handle finance and have worked at least one year. Before distribution, participants were given a brief explanation of the research objectives. Also, to avoid response bias in the survey, the respondent's name is filled with anonymous. The respondents got an explanation of the variables and terms used in the questionnaire. A total number of questionnaires distributed to respondents is 205 with a response rate of 100 percent, so that all are processed further for further analysis. The data collection period was one month.

\section{Result And Discussion}

\subsection{Descriptive Statistic}

The results of the analysis of factor demographic respondent can be seen in table 1 .

Table 1 Demographic profile of respondents

\begin{tabular}{llrr}
\hline \multicolumn{1}{c}{ Item } & & Frequency & Percent \\
\hline Gender & Male & 101 & 49.3 \\
Age & Female & 104 & 50.7 \\
& $<20$ & 84 & 41 \\
& $20-30$ & 76 & 37.1 \\
& $31-40$ & 21 & 10.2 \\
Education Level & $41-50$ & 16 & 7.8 \\
& $>50$ & 8 & 3.9 \\
& High school & 118 & 57.6 \\
& Diploma & 24 & 11.7 \\
Income & Bachelor's degree & 57 & 27.8 \\
& Post Graduate & 6 & 2.9 \\
& <Rp. 3,000,000 & 130 & 63.4 \\
& $>$ Rp. 3,000,000 & 75 & 36.6 \\
\hline
\end{tabular}


There were the almost equal proportion of male and female respondents, with female dominance, participated in the survey. The average age of the respondents was between 20 to 30 years, indicating that they are still in their productive age. Majority of the respondents were high schoolgraduate. There was 27.8 percent of university graduates, with bachelor degrees, working at Islamic boarding schools. Majority of respondents earn monthly income from below three million rupiahs. Table 2 presents the descriptive statistics of the variable under study.

Table 2 Descriptive statistics of variables

\begin{tabular}{lcrrrr}
\hline & N & Minimum & Maximum & Mean & Std. Deviation \\
\hline Perception Benefits & 205 & 3.00 & 5.00 & 4.2476 & .49072 \\
Perception ease of use & 205 & 2.00 & 5.00 & 4,0951 & .49269 \\
Perception Credibility & 205 & 2.50 & 5.00 & 3.8793 & .48984 \\
Subjective Norms & 205 & 1.00 & 5.00 & 3.7207 & .66679 \\
Trust & 205 & 2.30 & 5.00 & 3.9137 & .58746 \\
Attitude & 205 & 3.00 & 5.00 & 4,1005 & .52192 \\
Interest & 205 & 2.60 & 5.00 & 3,8907 & .42767 \\
Valid N (listwise) & 205 & & & & \\
\hline
\end{tabular}

Table 2 presents the descriptive statistics of each variable. The average response was statistically viable concerning perceive benefits, ease of use, credibility, subjective norms, trust, attitude and interest to use e-money. Perceive benefits on the technology is the most critical factors of consumers' attitude towards e-money, followed by perceived ease of use. Trust is an essential determinant of intention to use e-money or mobile payment for the transaction. Perceive security of the operation is crucial as everyone wants to protect valuable assets. 


\subsection{Validity and Reliability Test}

Table 3 Validity and reliability test of the instruments

\begin{tabular}{|c|c|c|c|c|c|c|c|c|c|c|c|c|c|c|}
\hline Variabel & Loading (L) & Error (E) & $L$ & $E$ & $L$ & $E$ & $L$ & $E$ & $L$ & $E$ & $L$ & $E$ & $L$ & $E$ \\
\hline X1_1 & 0.85 & 0.15 & & & & & & & & & & & & \\
\hline $\mathrm{X} 1 \_2$ & 0.82 & 0.18 & & & & & & & & & & & & \\
\hline $\mathrm{X} 1 \_3$ & 0.67 & 0.33 & & & & & & & & & & & & \\
\hline X1_4 & 0.62 & 0.38 & & & & & & & & & & & & \\
\hline X2_1 & & & 0.63 & 0.37 & & & & & & & & & & \\
\hline X2_3 & & & 0.81 & 0.19 & & & & & & & & & & \\
\hline X3_1 & & & & & 0.69 & 0.31 & & & & & & & & \\
\hline X3_2 & & & & & 0.59 & 0.41 & & & & & & & & \\
\hline X3_3 & & & & & 0.55 & 0.45 & & & & & & & & \\
\hline X4_1 & & & & & & & 0.58 & 0.42 & & & & & & \\
\hline X4_2 & & & & & & & 0.48 & 0.48 & & & & & & \\
\hline X4_3 & & & & & & & 0.89 & 0.11 & & & & & & \\
\hline X4_4 & & & & & & & 0.80 & 0.20 & & & & & & \\
\hline X5_1 & & & & & & & & & 0.67 & 0.31 & & & & \\
\hline$x 5 \_2$ & & & & & & & & & 0.83 & 0.17 & & & & \\
\hline $\mathrm{X} 5{ }_{-} 3$ & & & & & & & & & 0.76 & 0.24 & & & & \\
\hline $\begin{array}{l}\text { Y1_1 } \\
\end{array}$ & & & & & & & & & & & 0.65 & 0.35 & & \\
\hline Y1_2 & & & & & & & & & & & 0.77 & 0.23 & & \\
\hline Y1_3 & & & & & & & & & & & 0.67 & 0.33 & & \\
\hline Y2_1 & & & & & & & & & & & & & 0.49 & 0.51 \\
\hline Y2_2 & & & & & & & & & & & & & 0.49 & 0.51 \\
\hline Sum of Std.Loadings & 296 & & 1.44 & & 1.83 & & 2.75 & & 2.26 & & 2.09 & & 0.98 & \\
\hline Sum of Measur. Error & & 1.04 & & 0.56 & & 1.17 & & 1.25 & & 0.74 & & 0.91 & & 1.02 \\
\hline REUABILITY & 0.894 & & 0.787 & & 0.741 & & 0.8581 & & 0.873 & & 0.828 & & 0.485 & \\
\hline
\end{tabular}

According to Hair (1995), an indicator is considered valid provided it has a loading factor above 0.40. Based on the data above it is known that the data is valid. The next step is to test the reliability of the items used to measure the variables.

$$
\text { Contruct Re liability }=\frac{\left(\sum \text { Std Loading }\right)^{2}}{\left(\sum \text { StdLoading }\right)^{2}+\epsilon . j}
$$

The result of the reliability test revealed that two variables did not meet the reliability criteria. The variables were Y2_1 and Y2_2. The limit value used to assess an acceptable level of reliability is 0.7 . However, this value is not a dead value. This means that if the value below 0.70 , an item can still be accepted if accompanied by strong empirical reasons. Nunally and Bernstain (1994) in Ferdinand [16], stated that the reliability value between $0.50-0.60$ was enough to justify the results of the study.

\subsection{The Structural Equation}

The next step in the analysis is to put the variable into the structural equation. Picture 1 reflects the model. 


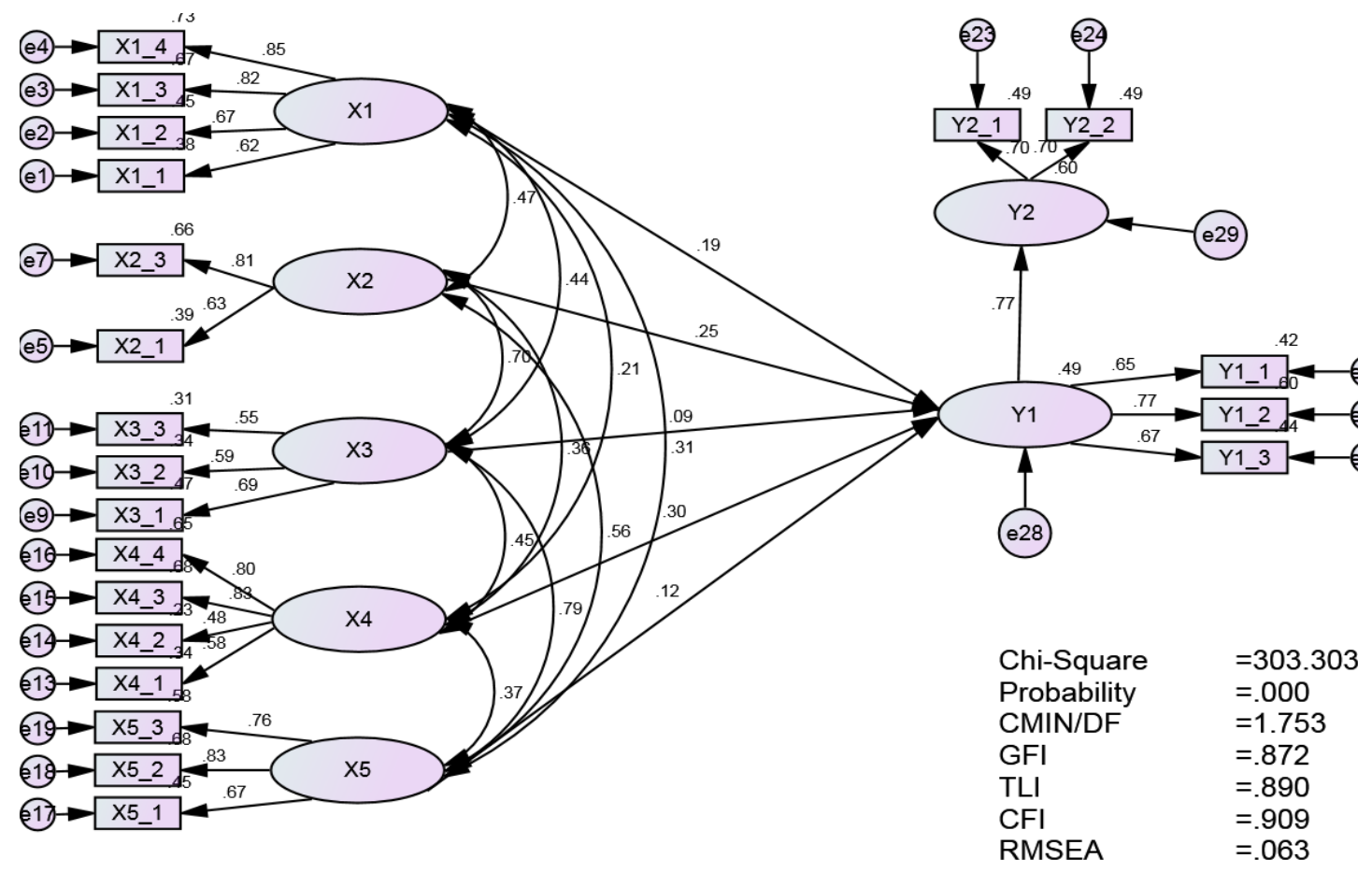

Picture 1 The structural equation modeling of the framework

The above output is the result of M-Payment testing using a mediating variable model with the following variables:

X1: Perceive benefits

X2: Perceive ease of use

X3: Perceive credibility

X4: Subjective norm

X5: Trust

Y1: Attitude

Y2: Interest

\subsection{Direct Effect Analysis}

Based on the output from testing the model using Amos shows that the immediate effect of perceived benefits on attitudes is 0.19 ; direct influence on perceived ease of attitude of 0.25 ; direct influence of credibility perception of 0.31 ; subjective norm's direct influence on attitudes of 0.30 ; the immediate effect of trust on attitude is 0.12 ; direct impact on attitudes towards interest of 0.77 . The loading factor value shows a strong direct relationship between independent variables and mediating variables. The negative value on the loading factor shows the rejection of the influence of the variable, but based on the output above shows that the independent variable has a good effect, then the mediating variable has a good impact on the dependent variable. 


\subsection{Evaluate the Goodness of Fit Criteria}

Based on the results of the analysis that we display on Amos Graphics or contained in the output table and the text output, we compare the values with the Cut of Value value for each criterion, so that the following results are obtained:

Table 4 Goodness of fit of the model

\begin{tabular}{rrrr}
\hline The goodness of Fit Index & $\begin{array}{r}\text { Research } \\
\text { Model Results }\end{array}$ & Cut off Value & Model Evaluation \\
\hline X2-Chi-Square & 303,303 & Small expected $<1000$ & Well \\
Significance Probability & 0,000 & $\geq 0.05$ & Well \\
RMSEA & 0.063 & $\leq 0.08$ & Well \\
GFI & 0.872 & $\geq 0.90$ & Pretty good \\
CMIN $/$ DF & 1,753 & 002.00 & Well \\
TLI & 0.890 & $\geq 0.95$ & Pretty good \\
CFI & 0.909 & $\geq 0.95$ & Pretty good \\
\hline
\end{tabular}

Based on the output above, it was found that [16]:

1. ${ }^{2}$ - Chi-Square statistics, the smaller the value $\chi^{2}$, the better the model, and the probability is accepted by the cut-off value of $p>0.05$. The results of this study indicate that this research model is in the right category because it has a small chi-square value.

2. RMSEA (The Root Mean Square Error of Approximation), is an index used to compensate for chi-square in a large sample. RMSEA values that are small or equal to 0.08 are indices for accepting the model based on the degree of freedom. The RMSEA value of this research model is 0.063 which means that the model is good so that the model can be accepted.

3. GFI (Goodness of fit Index), is a non-statistical measure that has a range of values between 0 and 1 . A high value in this index shows a " better fit." The GFI value of this study is quite good because it approaches the minimum criteria required.

4. CMIN / DF ( The Minimum Sample Discrepancy Function Divided with the degree of Freedom ), is a chi-square $\mathrm{X}^{2}$ statistic divided by the degree of freedom so that it is called $\mathrm{X}^{2}$ relative. Relative $\mathrm{X}^{2}$ value less than 2.0 or 3.0 is an indication of an acceptable fit between model and data. CMIN value of 1.753 indicates that this model is excellent and fit.

5. TLI (TuckerLewisIndex), an incremental index that compares a model that is tested against a baseline model, where the recommended value is $\geq 0.95$. However, the most important thing is that the value close to 1 indicates a perfect fit.

6. CFI (Comparative Fit Index), the range of values is $0-1$, which is getting closer to 1, indicating the highest level of fit.

Based on the results of the above analysis it can be concluded that the M-Payment testing model can be accepted. This is because the test output shows good results

The results of this study support the results of previous studies, which concluded that perceptions of benefits affect the interest in adopting e-money in transactions. This is consistent with several previous researchers [4]. Besides that, the perceived ease of operation also affects the interest in using e-money. The existence of government policies that began to lead to e-payment at individual facilities and the encouragement of using financial technology impacted consumers' decisions to use e-money. Perception of ease of use means that technology tools are easy to use and uncomplicated [38]. This supports previous research that the ease of positive influence on the 
intention to use a technology which later is followed by adoption [15]. Past studies indicate that customers' decision to adopt mobile payments have been used easily [29; 32, 2005, 33,34,38]

The results of this research study support previous research [33] in Malaysia which concluded that the perception of high benefits would result in a higher intention to adopt $\mathrm{m}$ payment. Similar results are also illustrated by [34] showing that m-payment adoption is useful concerning timesavings and portability. Perceptions of technological security risks are important things that determine consumers' decisions on whether to adopt innovations [18]. Therefore, perceived security in the transaction has a positive effect restricted ap intention to take m-payment. Starting from the belief that everyone will be sincere in transacting so that there is no fraud, the level of trust in payment assumes that no one will behave opportunistically by expecting the promised service (Adawiyah, 2015).

\section{Conclusion}

The study revealed that perceived ease of use, perceived usefulness, and subjective norms have a significant influence on the advertising of mobile payment. The study also confirms the relevance of users' intention to recommend mobile payment technology. Thus, future research needs to include social media cam campaigns and in future technology adoption studies. For researchers, the result is a basis for further refinement of personal technology acceptance model. For practitioners, understanding the key constructs is crucial to design, refining, and implementing mobile payment services, applications, and products that are high consumer acceptance, value, and high rates of positive recommendations in social networks.

\section{Acknowledgement}

Authors would like to thanks Universitas Jenderal Soedirman for funding this research

\section{References}

[1] Adawiyah, W. (2015). Impression management tactics, work-related behavior and perceived individual performance of sales clerks: a case of Indonesia. International Journal of Applied Business and Economic Research, 13 (7), 5481-5501.

[2] Adawiyah, WR, \& Pramuka, BA (2017). Scaling the notion of Islamic spirituality in the workplace. Journal of Management Development, 36 (7), 877-898.

[3] Adawiyah, WR, Pramuka, BA, Najmudin, and Jati, DP (2015). Green Supply Chain Management and its Impact on Construction Small and Medium Enterprises Sector (SMEs) Performance: A Case of Indonesia. International Business Management, 9 (6), 1010-1024.

[4] Adi, PH, Wihuda, F., \& Adawiyah, WR (2017). The role of social media browsing intention for behavioral outcomes of young consumers. Trziste = Market, 29 (1), 39.

[5] Allen, F., Demirguc-Kunt, A., Klapper, L., \& Martinez Peria, MS (2016). The foundations of financial inclusion: Understanding ownership and use of formal accounts. Journal of Financial Intermediation, 27, 1-30. doi: https://doi.org/10.1016/j.jfi.2015.12.003

[6] Ashraf, N., Karlan, D., \& Yin, W. (2010). Female Empowerment: Impact of commitment savings product in the Philippines. World Development, 38 (3), 333-344.

[7] Beck, T., Demirguc-Kunt, A., \& Martinez Peria, MS (2005). Reaching out: Access to and use of banking services across countries: The World Bank.

[8] Bruhn, M., \& Love, I. (2014). The impact of improved access to finance: Evidence from Mexico. The Journal of Finance, 69 (3), 1347-1376.

[9] Cheong, S.-N., Ling, H.-C., \& Teh, P.-L. (2014). Secure encrypted steganography graphical password scheme for access control system near field communication. Expert Systems with Applications, 41 (7), 3561-3568. 
[10] Davis, FD, Bagozzi, RP, \& Warshaw, PR (1989). User acceptance of computer technology: a comparison of two theoretical models. Management Science, 35 (8), $982-$ 1003.

[11] Demirgüç-Kunt, A., Honohan, P., \& Beck, T. (2008). Finance for all ?: Policies and Pitfalls in Expanding Access: World Bank.

[12] Demirgüç-Kunt, A., \& Klapper, L. (2013). Measuring financial inclusion: Explaining variation in use of financial services across and within countries. Brookings Papers on Economic Activity, 2013 (1), 279-340.

[13] Dupas, P., Green, S., Keats, A., \& Robinson, J. (2012). Challenges in banking the rural poor: Evidence from Kenya's western province. Retrieved from

[14] Dupas, P., \& Robinson, J. (2013). Savings constraints and microenterprise development: Evidence from a field experiment in Kenya. American Economic Journal: Applied Economics, 5 (1), 163-192.

[15] Dutot, V. (2015). Infected near field communication (NFC) factors adoption: An extended TAM approach. The Journal of High Technology Management Research, 26 (1), 45-57.

[16] Ferdinand, A. 2005. Structural Equation Modeling. Semarang: The Board of Directors of Diponegoro University

[17] Group, WB (2016). World Development Report 2016: Digital Dividends: World Bank Publications.

[18] Hari Adi, P., \& Adawiyah, WR (2018). The impact of religiosity, environmental marketing orientation, and practices on performance: A case of Muslim entrepreneurs in Indonesia. Journal of Islamic Marketing.

[19] Honohan, P. (2008). Cross-country variation in household access to financial services. Journal of Banking \& Finance, 32 (11), 2493-2500.

[20] Istiqomah, \& Adawiyah, WR (2018). Development of rural entrepreneurship groups in Indonesia: benefits, problems, and challenges. International Journal of Entrepreneurship and Small Business, 34 (3), 330-342.

[21] Kendall, J., Ponce, A., \& Mylenko, N. (2010). Measuring financial access around the world: The World Bank.

[22] Klapper, L., El-Zoghbi, M., \& Hess, J. (2016). Achieving the sustainable development goals. The role of financial inclusion. Available online: http: // www . bro. Org. Accessed, 23 (5), 2016.

[23] Lu, L.-C., Chang, H.-H., \& Yu, S.-T. (2013). Online shoppers 'perceptions of e-retailers' ethics, cultural orientation, and loyalty: an exploratory study in Taiwan. Internet Research, 23 (1), 47-68.

[24] Madlmayr, G., Langer, J., Kantner, C., \& Scharinger, J. (2008). NFC devices: Security and privacy. Paper presented at Availability, Reliability and Security, 2008. ARES 08. Third International Conference on.

[25] Ondrus, J., \& Pigneur, Y. (2007). An assessment of NFC for future mobile payment systems. Paper presented at the Management of Mobile Business, 2007. ICMB 2007. International Conference on the.

[26] Ooi, K.-B., \& Tan, GW-H. (2016). Mobile technology acceptance model: An investigation using mobile users to explore smartphone credit cards. Expert Systems with Applications, 59, 33-46.

[27] Owens, J. (2013). Offering Digital Financial Services to Promote Financial Inclusion: Lessons We Learned. Innovations: Technology, Governance, Globalization, 8 (1-2), 271 282.

[28] Ozili, PK (2018). Impact of digital finance on financial inclusion and stability. Borsa Istanbul Review. doi: https://doi.org/10.1016/j.bir.2017.12.003 
[29] Park, SY (2009). An analysis of the technology students 'acceptance model in understanding university' behavioral intention to use e-learning. Educational technology \& society, 12 (3), 150-162.

[30] Pinasti, M., \& Adawiyah, WR (2016). CO-OPETITION TO PROMOTE GROWTH OF BATIK SMALL AND MEDIUM ENTERPRISES. International Journal of Business \& Society, 17 (3).

[31] Putri, NK, Adawiyah, WR, \& Pramuka, BA (2017). Independence of Audit Ethical Decision Making Process: A Case of Indonesia. DLSU Business \& Economics Review, 26 (2), 1-1.

[32] Saadé, R., \& Bahli, B. (2005). The impact of cognitive absorption on perceived usefulness and perceived ease of use in online learning: an extension of the technology acceptance model. Information \& Management, 42 (2), 317-327.

[33] Tan, GW-H., Ooi, K.-B., Chong, S.-C., \& Hew, T.-S. (2014). NFC mobile credit card: the next frontier of mobile payment? Telematics and Informatics, 31 (2), 292-307.

[34] Teo, A.-C., Tan, GW-H., Ooi, K.-B., Hew, T.-S., \& Yew, K.-T. (2015). The effects of convenience and speed in m-payment. Industrial Management \& Data Systems, 115 (2), 311-331.

[35] Teo, AC, Tan, GWH, Cheah, CM, Ooi, KB, \& Yew, KT (2012). Can the demographic and subjective norms influence the adoption of mobile banking? International Journal of Mobile Communications, 10 (6), 578-597.

[36] Tsai, H.-y. S., \& LaRose, R. (2015). Broadband Internet adoption and utilization in the inner city: A comparison of competing theories. Computers in human behavior, 51, 344355.

[37] Valcourt, E., Robert, J.-M., \& Beaulieu, F. (2005). Investigating mobile payment: supporting technologies, methods, and use. Paper presented at the Wireless and Mobile Computing, Networking and Communications, 2005. (WiMob'2005), IEEE International Conference on.

[38] Venkatesh, V. (2000). Determinants of perceived ease of use: Integrating control, intrinsic motivation, and emotion into the technology acceptance model. Information systems research, 11 (4), 342-365.

[39] Venkatesh, V., Morris, MG, Davis, GB, \& Davis, FD (2003). User acceptance of information technology: Toward a unified view. Quarterly MIS, 425-478.

[40] Wihuda, F., Kurniawan, AA, Kusumah, AI, \& Adawiyah, WR (2017). Innovative behavior: A study from the hotel industry. Turizam: medunarodni znanstveno-stručni časopis, 65 (3), 294-313.

[41] Zins, A., \& Weill, L. (2016). The determinants of financial inclusion in Africa. Review of Development Finance, 6 (1), 46-57. doi: 10.1016 / j.rdf.2016.05.001 